\title{
Telling tales: Using storytelling to teach EFL kindergarten students in Taiwan
}

\author{
Hsu, Tsu-Chia Julia $\bowtie$
}

Department of Applied Foreign Languages, Lunghwa University of Science and Technology, Taiwan, ROC (hsuinuk@gmail.com)

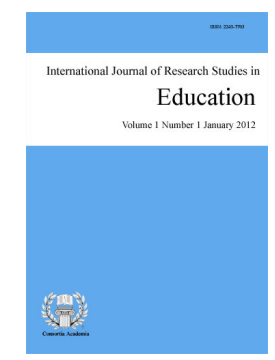

ISSN: 2243-7703 Online ISSN: 2243-7711

OPEN ACCESS

\section{Abstract}

Recently, the pressure of producing globally competitive graduates has furthered the need of students to enhance their English proficiencies; this is especially true for students who major in English and will be teachers in the near future. Many EFL teachers have used storytelling as a resource when teaching. More so, storytelling is said to be able to provide a motivating and interacting vehicle between students and teachers for language learning. The strategy given in this study is meant to help teachers to use storytelling as a resource for young EFL learners. The study focuses on specific instructional outcomes from using storytelling as a group teaching strategy and investigates how storytelling in teaching meets the needs of teachers. The primary purpose of the study aims to explore how storytelling in teaching affects EFL children's learning. Finally, the strengths and weaknesses of using storytelling as a group teaching strategy will be discussed. The research design is to use a questionnaire and group interviews. The pre-service teachers have kept a daily journal to incorporate reflections and observations and record them on the students' log. In addition, the coordinator's and the researcher's log provided valuable summary observations. Results showed that pre-service teachers' teaching styles might need to employ creativity, which then helps them gain the children's attention as the teachers interact with them. Implications and suggestions of the study are of great importance for further research.

Keywords: EFL children; learning motivation; storytelling; creativity; teacher preparation 


\section{Telling tales: Using storytelling to teach EFL kindergarten students in Taiwan}

\section{Introduction}

English language education in elementary school aims to provide students with the opportunity to develop their communicative competence while learning to appreciate different cultures; such opportunities have said to help foster national competitiveness and the overall quality of citizen's livelihood (Hung, 2009). However, when using a traditional teaching mode, teachers continually ask children to memorize words and grammar, furthermore they have the children do more than enough homework every day. This gives students a dislike for English; thinking and learning English then becomes a difficult and boring thing; and finally the children would tend to lose any motivation to learn English. Hence, this study is used the storytelling method to motivate children to learn English.

In Taiwan, EFL teachers are focusing on effective language teaching pedagogy in class. EFL teachers continue to be interested in story telling as a resource while teaching (Dujmović, 2006). Among these language pedagogy, storytelling strategy has been a practical and useful teaching tool, particularly in language learning (Tsou, Wang, \& Tzeng, 2006). Often time children consequently find more fun in it. Because there are no words in a picture book, the pictures in it are very characteristic and can attract the attention of readers. We see that the world through children's eyes is different from that of adults ( $\mathrm{Wu}, 2008)$. Through storytelling, it is hoped that it shall investigate whether EFL children will promote their engagements and imaginations, at the same time increase their learning motivation, and decrease their anxieties.

Ahern, Bermejo, and Fleta (2008) urge that "Stories help children develop not only in language skills and other areas of the curriculum, but they also help develop children's positive attitudes" (p. 100). Stories are an important resource of vocabulary, intonation, grammatical structures, and patterns in a real context. Language in storybooks is not referential as in textbooks, but representational, and characters in storybooks think, talk, cry or shout just like in real life. In addition, stories are said to have help children develop not only in language skills and other areas of the curriculum, but they also can help improve children's positive attitudes. In short, using stories in class can provide language learners many opportunities for unconscious and indirect ways of effective language learning.

Fitzgibbon and Wilhelm (1998) prove that "The arguments for teachers using stories in the classroom are found in case studies ranging from pre-school through university level classrooms. Most deal with how stories are used, both when the teacher is the storyteller and when students are the storytellers" (p. 23). Cooper's (1989) remarks for first language children, storytelling is being promoted as an "ideal method of influencing a child to associate listening with pleasure, and of increasing a child's attention span and retention capacity, as well as broadening vocabulary, and finally of introducing a child to the symbolic use of language" (p. 71). In so doing, using a storytelling strategy can assist teachers to influence children in a number of ways.

Most of the previous studies on storytelling describe a post-text activity as an example of a learner-centered process that guides students to apply information and conveys messages to others (Ling, 2009). Some studies report that problems arose while storytelling in teaching, and provide suggestions for improvement. Other studies prove that $88 \%$ of the students enjoyed the storytelling classes. Most learners feel that they can learn four skills of language; these include listening, speaking, reading and writing through storytelling classes. In addition, they also enjoy discussing the story content with others.

In a seminal literature, Chomsky (1972) argues that the best thing for adults helping young learners acquire language would be exposed themselves to a variety of language input in the form of interesting and stimulating stories. This indicates that learners can try to learn and understand language from stories. One of the strengths for beginners is that storytelling can be seen as an interesting language skill to teach learners. It can also inspire 
Telling tales: Using storytelling to teach EFL kindergarten students in Taiwan

their imagination, and make the world colorful. However, only two studies investigate how kindergarten EFL children developed the concept of reading through stories. Chien and Huang (1999) use The Emergent Reading Behavior Inventory to investigate whether children behave differently after a year of storytelling. Researchers prove that children can make significant progress in concepts about print, e.g. book awareness, print direction, print awareness, suggesting that children can develop print awareness through literacy activities before formal reading instruction begins. Analysis showed that children could use the graphic-phonemic connection to read unknown words without being taught phonics.

Most of the studies mentioned above remain short-term, lasting a year or less, a three and a half year longitudinal qualitative study using storytelling in an after-school program in Taiwan has provided a great deal more information. Lee (2008) claims that those children who are taught by storytelling for a period of time can not only learn the attitude of the stories but take suggestions from the stories seriously when they are dealing with the same situation.

The purpose of the study is to explore EFL children's learning effect through storytelling in teaching. The specific aim is to investigate whether storytelling in group teaching strategy can enhance EFL children's learning motivation. Moreover, children can be stimulated to use their imagination by the storytelling method. Furthermore, it investigates whether EFL teachers can also meet their needs. In particular, how children's creativity can be stimulated from extended story activities and how children's interest is encouraged through practices in teaching. The purpose focuses on specific instructional outcomes while using storytelling as a group teaching strategy. Finally, strengths and weaknesses towards storytelling in a group teaching strategy will be discussed.

\section{Theoretical Framework}

There are two main teaching methods using in the study supported by research: one is regarded as cooperative learning and the other, storytelling. Cooperative learning (CL) is considered as an instructional use of small groups so that students work together to maximize their own and each other's learning (Johnson \& Johnson, 1992). CL has been defined as "group learning activity organized so that learning is dependent on the socially structured exchange of information between learners in groups and in which each learner is held accountable for his or her own learning and is motivated to increase the learning of others" (Olsen \& Kagan, 1992).

Cooperative learning, known as jigsaw, learning together, group investigation, student teams-achievement divisions, and teams-games-tournaments, indicates a collection of group teaching method with an instructional arrangement for teaching collaborative skills to small, heterogeneous group of learners (Rich, 1993; Sharan, 1980). CL has been defined as "instructional strategies which depend on the interaction of a small group of learners as a central feature of classroom learning tasks" (Dodl, 1990, p. 344). A small group is considered as a small collection of individuals interacting with one another in reciprocal influence (Schmuck \& Schmuck, 1988).

Furthermore, there are a great number of strengths for instructors in practicing CL with students in the class. For example, According to Orr (1997), working together results in a greater understanding than would likely have occurred if one had worked independently. In contrast, Mathews (1992) describes that some educators have challenged the use of cooperative learning in classrooms with students who are identified as "gifted," claiming that gifted students become permanent tutors and are resentful of having to work with students of differing abilities.

Storytelling is described as "a technique of teaching that has stood the test of time" (Chambers, 1970). With first languages children, storytelling is being promoted increasing a child's attention span and retention capacity (J. L. Cooper, Robinson, \& McKinney, 1990; P. Cooper, 1989). More recently, storytelling has been promoted as an effective way to teach the English language to non-native speakers. Stories are valued as providing comprehensible input that facilitates language acquisition (Hendrickson, 1992). In addition, Pedersen (1995) 
advocates teachers as storytellers and storytelling as pedagogical method. Stories help to communicate literary and culture heritage while also helping learners better develop a sense of rhetorical structure which assists in the study of literature and in their own writing.

In addition, there are many kinds of art forms, as Dujmović (2006) defines, "Storytelling, the art of narrating a tale from memory rather than reading it is one of the oldest of all art forms, reaching back to prehistoric times". According to Serrat (2010) "Storytelling is the vivid description of ideas, beliefs, personal experiences, and life-lessons through stories or narratives that evoke powerful emotions and insights". Moreover, storytelling can influence audiences through stories or narratives. In addition, Satish, Jain, and Gupta (2009) define storytelling as a two-step process in which a storyteller can retrieve appropriate events and associated data, and then those are further filtered using preferences of the viewer. On the other hand, students will be touched by stories and teachers can enhance students' thinking and learning. Stories can also develop the individual's imagination and interests. It helps engage the students in the class. Furthermore, teachers can easily correct students if they have negative thinking.

Moreover, stories are found in ancient times with different forms. For example, the oral story, the transcribed story, and the literary story have existed since the beginning of time. Yolen (1986) addresses, "Storytelling, the oldest of arts, has always been both an entertainment and a cultural necessity ...storytellers breathed life into human cultures" (p. 1). The formal telling of stories has a history full of treasure and delight. Evan informally, in daily conversations, the use of storytelling to communicate ideas and to express one's experience is evident. Stories are passed frequently between people; children tell stories to their imaginary playmates and adults tell their childhood stories to their children.

Stories are told to entertain, inform, educate, enlighten, and simply emote. Hoffer (1955) claims that humans have an innate need to tell stories, and we must story our lives to make order and sense out of them. $\mathrm{He}$ emphasizes that, "Man is eminently a storyteller. His search for a purpose, a cause, an ideal, a mission and the like is largely a search for a plot and a pattern in the development of his life story - a story that is basically without meaning or pattern" (p. 62). In addition, stories give meaning to life. Some even indicate that educators use stories to give meaning in learning (Hoffer, 1955). Hence, a story tends to have more depth than a simple example.

A story tells about some event - some particular individuals, and something that happens to them. Stories engage our thinking, our emotions, and can even lead to the creation of mental imagery (Green \& Brock, 2000). In particular, stories can be used in today's classroom with a diversity of functions, including sparking student interest, aiding the flow of lectures, making material memorable, overcoming student resistance or anxiety, and building rapport between the teachers and the learners, and among students themselves (Green, 2004).

According to Bas (2008), storytelling has an immediate advantage for students, for example, "Storytelling helps children to link fantasy with the real world. Moreover, most children are familiar with most of the stories, so they work with familiar contexts when they work with stories" (p. 197). On the other hand, instructors can also "use picture strip stories where students are expected to re-tell a story by using the visuals" (Ersöz et al., 2006). Ahern et al. (2008) proves that stories are important sources of vocabulary, intonation, grammatical structures, and patterns in real context. Language in storybooks is not referential as in textbooks, but representational, and characters in storybooks think, talk, cry or shout just like in real life. Moreover, "Stories help children develop not only language and other areas of the curriculum, but they also help develop children's positive attitudes." In short, using stories in class can provide opportunities for unconscious and indirect ways of effective language learning.

Employing storytelling in the classroom on a regular basis is a sound teaching/learning strategy because it builds on children's preschool strengths and oral language expertise to help them successfully develop social, intellectual, and linguistic competencies (Craig, 1996). In so doing, stories can promote the comprehensive development of children's comprehension, memory, imagination, judgment, and verbal ability, especially in the 
Telling tales: Using storytelling to teach EFL kindergarten students in Taiwan

early learning stage story teaching may be creating a multiplier effect. Not only does the content of the story excite learners, often because the story contains a coherent plot, but also it can trigger children's interest, attention and emotional response.

\subsection{Research questions}

The study includes three research questions as follows:

$>$ To what extent can storytelling in group teaching meet the needs of teachers?

$>\quad$ What are the strengths and/or weaknesses of storytelling in a group teaching strategy?

\section{Method}

This study adopts an action research methodology. Utilizing action research in the practitioner's teaching practice is an important source of learning for teachers. Action research is a process; it is an on-going development and evaluation of new teaching modules (McKernan, 1991). Therefore, the goal of an action research is to approach teaching, and to improve the teaching and learning practices. In sum, the scope of action research as a method is impressive. It can be used in almost any setting where a problem involving people, tasks and procedures cries out for solutions (Cohen, Manion, \& Morrison, 2007).

\subsection{Participants}

The learners - The duration of the study lasted 2 months, starting from the beginning of November to the end of December 2012, and the study group selected the four-year-old kindergarten program (K4) at one of the branches of bilingual kindergartens around the island. This case where the action research took place only selected one out of three K4 classes, for a total of 21 children. The learners selected from the study have been evaluated through observation of learners' reactions among three different groups. The chosen group was asked for the informed consent, and the subjects have provided the forms by their parents before the project. Their family seemed to be willing to have their children get involved in this storytelling project because the pre-service teachers (PT) not only taught the storytelling materials and games, but they also provided lots of opportunities for students employing their creativity to speak English from the class to the smaller groups. Learning materials incorporated a variety of methods, such as pretend play, picture books, paint and other art materials, and other class toys such as pegboards, and puzzles. Teachers worked with individual children, small groups, and the whole group at different times during fifty minutes, a total of five times.

The Teachers - Six college PT all majors in Applied Foreign Languages (AFL) made up a study group; they were trained to storytelling in teaching plan, and reinforced children's creative ideas as well as English speaking skills in every activity. Before this joint storytelling project, each PT filled out the informed consent and submitted to the AFL department. In addition, the PTs constantly assessed the significance and value of each lesson plan and group activities during the duration of reflection and feedback, and then revised the lesson project before teaching. After the advisor gave feedback to all, they learned how to make progress from what they taught each time, and kept a positive attitude and continued taking action for the study.

The Observers - The coordinator and the researcher served as one of the observers in this study. She not only initiated the pilot study and screening the ideal PTs for the study, but also she provided summary observations during the process of collecting information. Since this study regarded as action research, PTs also played the roles of observers and kept a daily journal to incorporate reflections; their observations have been considered as a pivotal research activity in the making of research results. In addition, they kept records to achieve the teaching goals required triangulation of multiple methods, data sources, and viewpoints. This study not only documented the participants' thoughts and feelings about every practice during and after teaching lessons; but it also required the PTs careful observation for further understanding the significant feedback tips 
Hsu, T.-C.

from each other while writing observation logs. In addition, the coordinator's and the researcher's log provided summary observations on site.

\subsection{Research tools}

A considerable range of areas in second language research has employed questionnaires as a means of collecting data (Gass \& Mackey, 2007). The questionnaire mostly provided questions targeted at receiving specific information on many kinds of topics. In this study, three-part questionnaire included the first section on open-ended questions with regard to their personal information, and section two presented the teachers' opinions regarding the sample lessons. Some samples of these items along with the 5 point Likert scale (1: Strongly disagree, 2: Disagree, 3: Neither agrees nor disagrees, 4: Agree, 5: Strongly agree) used to respond to Table 1 (See the result), are presented here:

\section{Teaching tasks in class in English}

1. The tasks are appropriate for group of students.

2. Creativity is encouraged in this story lesson.

3. The story is too easy for the group of students.

4. This lesson helps my students integrate their language skills

\section{Teacher's overall opinions regarding the story in teaching}

1. I don't like teaching.

2. The reason that I do not like the lessons was because I do not find the topic interesting.

3. The reason that I like the lesson was because of the topic.

4. The choice of these topics motivates my students to learn.

All questions aimed at the PTs' perception concerning lessons preparation for teaching and overall opinions toward teaching. By discussing some of the ways in which the questionnaire has evolved and investigated by five experts in the field of second/ foreign language teaching in Taiwan's higher education, which its content validity was obtained from the experts judging and used their suggestions by the proof of the valid and reliable measure.

After all the lessons were taught, questionnaires were completed by all the participants. It consisted of two sections: the first one indicated open-ended questions concerning general individual information and the second one, a total of fifteen statements in a form of ranking scale, listed overall opinions regarding teaching preparation and teaching opinions. The respondents need to answer the scale indicated individual strength or agreement or disagreement with each question, from one to five. The questionnaires completed by the PTs were based on the individual's understanding of the content with each statement.

\subsection{Procedure}

The participants were informed of a pre-meeting among the school staff, native teachers, and the experiment group children. The purpose of setting up this meeting was to inform all related school personnel and teachers, and the research team to meet the study group needs and to support the PTs towards lesson teaching. Starting in mid-November to the end of December, a total of five weekly teaching lessons were done within six weeks, and the duration remained fifty minutes for each lesson. The first lesson presented a one-hour ice breaker lesson before the actual teaching. Such a warm-up ice-breaker activity enabled the PTs to acquire an understanding of the experiment group and the classroom's actual environment. The pilot activity plan also enabled the PTs to make minor changes to lesson plans if necessary. Following that, there were four story books were provided to the PTs for each lesson, and they designed a variety of activities suitable for the lesson objectives and needs of the experiment group learners.

This study employed a descriptive research paradigm; a qualitative research that is concerned with how 
Telling tales: Using storytelling to teach EFL kindergarten students in Taiwan

something that exists is related to some preceding event that has influenced or affected a present condition or event. Additional qualitative data were also gathered in the form of PTs' daily logs. They were required to write a teaching log during the entire duration of the teaching program and were asked to note their experiences and comment in their logs.

\section{Results}

The results of the study showed three major data collections, namely, teachers' log, questionnaire and coordinator's log. The pre-service teachers kept a daily journal to incorporate reflections and observations on site. They were followed by analyses of each set of results according to each group. In the following, an overall analysis presented all research findings.

\subsection{Results of Teachers' questionnaire}

In this section, the result of teacher's questionnaire is revealed, and is followed by an analysis. The results are illustrated as given below:

\section{Table 1}

Questionnaire: Teacher's overall opinions regarding the storytelling in group teaching

\begin{tabular}{|c|c|c|c|c|c|c|}
\hline & Statements & 1 & 2 & 3 & 4 & 5 \\
\hline 1. & The tasks are appropriate for group of students. & & & & $66 \%$ & $34 \%$ \\
\hline 2. & Creativity is encouraged in this story lesson. & & & & $50 \%$ & $50 \%$ \\
\hline 3. & The story is too easy for the group of students. & & $34 \%$ & $50 \%$ & $16 \%$ & \\
\hline 4. & This lesson helps my students integrate their language skills & & $17 \%$ & $17 \%$ & $66 \%$ & \\
\hline 5. & Children have motivation to participate in the group activity. & & & & $66 \%$ & $34 \%$ \\
\hline 6. & $\begin{array}{l}\text { Children interact with their group less actively compared to their usual } \\
\text { performance. }\end{array}$ & & $50 \%$ & $34 \%$ & & $16 \%$ \\
\hline 7. & $\begin{array}{l}\text { Frequent use of the sentences patterns and words is present in the } \\
\text { group. }\end{array}$ & & $16 \%$ & $34 \%$ & $50 \%$ & \\
\hline 8 . & Most group children actively interact with me. & & & & $84 \%$ & $16 \%$ \\
\hline 9. & The length of whole lesson is too long. & & & $50 \%$ & $34 \%$ & $16 \%$ \\
\hline
\end{tabular}

All female pre-service teachers were seniors who majored in Applied Foreign Languages; they have indicated the length time of preparation for about many meetings and the followed-up reports, including the individual's understanding the content suitable for children and how each reached the objectives of lesson plans. Table 1 presents the teachers' questionnaire and consists of two parts: open-ended questions with regard to their personal information and teachers' opinions regarding the sample lessons. According to the teachers' survey in Table one, all results (66\% and/or above agree), except for statement 3 (34\% disagree) and 6 (50\% disagree), showed that most teachers agreed that the sample lessons were suitable for children, and that the creativity stimulated from extended story activities for children was encouraged while the teachers practiced taught. In addition, results from 5 to 9 revealed that the children had motivation and actively interacted with one another in groups by teachers' guidance.

It was found that the children could easily be distracted and did not seem to reciprocally interact with others in some circumstances as indicated in the results of statement 6 (50\% disagree). Children easily lessened attention in class without clear guidance. It suggests that pre-service teachers need to provide more constructive guidance and commands for children with short attention spans. According to the results of statement 3 (66\% agree) it was revealed that all stories seemed easy for children to associate with the ending and/or the center of the stories. In so doing, it suggests that teachers should also find enough flexible stories with more adventure plots in them and that that would stimulate children's critical thinking. As shown in the results of Table 1, these overall answers suggest that the lesson plans were suitable in design for this age group of children. We could likely say that the lesson plans supported the significance of storytelling in group teaching to meet the needs for the overall objectives. 


\section{Table 2}

Questionnaire: Teacher's overall opinions regarding the story in teaching

\begin{tabular}{|c|c|c|c|c|c|c|}
\hline & Statements & 1 & 2 & 3 & 4 & 5 \\
\hline 1. & I don't like teaching. & & & & $84 \%$ & $16 \%$ \\
\hline 2. & $\begin{array}{l}\text { The reason that I do not like the lessons was because I do not } \\
\text { find the topic interesting. }\end{array}$ & & & & $84 \%$ & $16 \%$ \\
\hline 3. & The reason that I like the lesson was because of the topic. & & & $34 \%$ & $66 \%$ & \\
\hline 4. & The choice of these topics motivates my students to learn. & & & $17 \%$ & $66 \%$ & $17 \%$ \\
\hline 5. & The topics are doable in a language classroom. & & & & $84 \%$ & $16 \%$ \\
\hline 6. & $\begin{array}{l}\text { I would like to participate in the teaching session related to the } \\
\text { topic if I have another teaching opportunity. }\end{array}$ & & $17 \%$ & & $66 \%$ & $17 \%$ \\
\hline
\end{tabular}

All teachers' responses to the survey (See Table 2), and all results (66\% and above agree), except for the statement 15 (17\% disagree), showed that the majority of teachers approved and that they enjoyed teaching the sample lessons by the selection of topics, such as A Color of His Own, Does a Kangaroo Have a Mother, too, A Caterpillar, Santa Clause, and so on. Thus, appropriate lesson topics for storytelling in teaching not only helped these teachers enjoy teaching topics, but they could also reinforce children' learning motivation and further enhance their creativity and critical thinking.

However, some teachers after teaching also reported difficulties in demonstrating storytelling activities in their class. According to the result of Table 2, it was found that one out of six pre-service teachers seemed not to undertake the future teaching opportunities. Sometimes, children's learning attitudes and/or emotional resistance could reciprocally influence teachers, and that can prevent intern teachers from working with students after graduation. It suggests that intern teachers need to immediately reflect on this after they encounter difficulties in teaching. In so doing, they would get more group rapport or resource support if necessary; the other need was to attain more understanding about learners' behavior conduct. That could help build up teacher-student relations in the process of actual teaching preparation for a future within the classroom.

\subsection{Results of the journal reflections and observations}

Within this section, the pre-service teachers using journals incorporated reflections and observations on site. The following examples and detailed explanation indicated the strengths and weaknesses for each group. In the Orange group, there were 4 boys, A, B, C, D, and one girl named E.

\section{Orange Group}

The strength:

In the Orange group, I find that children would help one another complete in the "Spot the Differences" activity, which would engage all to try to find 10 things that are different. For example, E couldn't find enough differences on the paper sheet, and the other children helped her finish the rest of the differences on the paper. (Orange Group Tutor P-female, 21)

Within this case, E seldom interacted with the rest of the group during group task time. The tutor needed to provide her with many opportunities to get involved in the group with lots of encouragement. As a matter of fact, the other group children were a good influence on her by helping her in finishing the rest of group tasks. Besides, this group showed strong positive interdependence, especially during the group game. When the rest of the group needed help, they would help one another. Some children were used to actively joining group activities, and the others would be affected by positive group peers.

The weakness:

In order to get more space, D pushed the girl E when they were drawing the pictures. In this case, there was some conflict in the group. In addition, some children played and talked with other 
children and that caused them to lose attention in the game or class (Orange Group Tutor P-female, 21).

And:

Children had conflict and argued easier in the group. In the drawing picture game, I asked the children to sit down and draw the picture. Because boy $C$ thought that the drawing space for him was too small, so he pushed Catherine. I also found that some children easily lost their attention. They played and talked with one another in the lesson, 'The very hungry caterpillar.' (Orange Group Tutor P-female, 21)

The children's thinking was not rationale, and they easily showed their emotional feelings. Perhaps some reasons were caused by conflict between some group children. According to the authorities, children's attention is only maintained for 10-15 minutes, and they like to play with their friends, so sometimes the children did not focus on the teacher.

\section{Tomato Group}

There were four children in the Tomato group including 2 boys named $\mathrm{N}$ and $\mathrm{Q}$ and 2 girls named $\mathrm{O}$ and $\mathrm{P}$.

The strength:

In the game 'Recognizing Animal', all of group children are aggressive in answering questions and also want to tell me which animals they like. (Tomato group Tutor, A-female, 21)

And:

When playing the 'Puzzle Games', boy $Q$ and girl $P$ share what they have to others and like to tell others how to make puzzles complete. In so doing, children in the group show their interdependence and cooperation. (Tomato group Tutor, A-female, 21)

Interestingly, children in this group showed much more positive results, and they also enjoyed interacting with their tutor.

The weakness:

Some children would be too self-centered and like to interrupt me when I am talking. For example, boy $N$ would interrupt me while I am talking in the group. In addition, girl $O$ would answer nothing, but does her color drawing silently. Sometimes, the rest of the group children are out of control while I am talking to one of them. (Tomato group Tutor, A-female, 21)

While children were playing the game 'Drawing Chameleon,' everyone had different color papers they liked. They chose their favorite colored papers and cut the colored ones into small pieces and pasted them on the group paper together. However, some only cared for their own things, and did not share with others. They would share colored papers they had after the tutor asked them to do so. However, boy $\mathrm{N}$ did not share his purple papers with others until the tutor praised boy $\mathrm{Q}$ as he shared his green papers to others. So boy $\mathrm{N}$ changed his negative attitudes to share things with other group members.

\section{Banana Group}

In the Banana group, there were 3 boys, $\mathrm{R}, \mathrm{S}$, and $\mathrm{T}$, and one girl named $\mathrm{U}$. When the children were in a small group, they concentrated on the group activities for the past few weeks, including drawing pictures, sentence drills, jig saw, go fishing, etc. They enjoyed helping each other while tutors asked questions. However, one member, T, slowly answered questions most of the time; and the other, U, responded the tutor's questions in a soft voice. 
The strength:

For example, in the last class we had a game that is 'Decorating Christmas Tree' with the previous class activities. The group members exchanged their own decorations and posted on the tree. When I asked, 'What color is the ginger bread?' They said, 'It's blue or any kind they saw.' When $T$ and $U$ answer in a soft voice, $R$ and $S$ will help the other two members answer the teacher's question. (Banana Group Tutor, M-female, 22)

In so doing, children, especially in the group, helped each other show their independence and cooperation; moreover, they would produce the group accountability for a group objective.

The weakness:

In order to increase children's confidence and encourage them to answer questions, we tutors provide a variety of stickers for children who answer questions eagerly.

...but sometimes they are easily distracted by the stickers because children would compare their own stickers with other children's. In addition, they would like to exchange theirs with one another. Sometimes, this behavior, to exchange stickers with one another, would delay the group in progress. (Banana Group Tutor, M-female, 22)

In this case, there was a little distraction during the group process in doing exchanging stickers, and some seemed rarely answered the tutor's questions.

\section{Cherry Group}

In the Cherry group, there are 2 boys, J, K and 2 girls, L, M.

The strength:

When children are in the small group, I find that they can pay more attention in class. All children take part in activities positively, because they want to get stickers and teacher's praise. In this group, children would help each other and try to complete one thing together.

In the game 'Find Candy Canes', they would try to find all candy canes on the paper sheet. For example, girl L and boy $K$ couldn't find candy canes on the paper sheet, and the other member named $M$ told them where the candy canes were and helped them finish the game. (Cherry group, Tutor V-female, 21)

The weakness:

Two girls in this small group were easily arguing with each other, except for the other two boys, because they had different opinions:

For example, in the game 'Drawing Chameleon', everyone held they liked color and pasted it on paper. Girl L wants to use a pink color on paper but girl M didn't like pink, she wanted to use orange. They conflicted with each other because they have different opinions. (Cheery Group Tutor V-female, 21)

And:

In the "Puzzle Game", I found that if I repeated in playing the same game, some children started to feel bored and lost patience. They started to talk and impact each other, this lead their lack of concentrate in class. (Cherry Group Tutor V-female, 21) 


\section{Apple Group}

In the Apple group, there were 3 boys, G, H, I, and one girl named F. When the children are in the small group, they can engage in group activities and they reciprocally influence one another.

The strength:

For example, children can share their piece of puzzle with other members in the puzzle games, in order to help other children and together finish for one thing in the small group. Children also are more competitive when they are in a small group because children want to get a reward, they would be positive to answer teacher's question and quickly finish their task, then they can get stickers or teacher's admiration. We can find that children show much interdependence and group cooperation when they in small group to finish group objectives. (Apple Group Tutor D-female, 21)

The weakness:

In the small group, children could not concentrate easily, partly because some children would easily influence other children, teachers sometimes would lose control of children.

...children are close to one another in the small group, so they more easily can do their own things or talk and play with one another; small groups easily let children get distracted that is a disadvantage. (Apple Group Tutor D-female, 21)

The tutor found the key for the group losing control is that one is influenced by others, if one child was willing to answer the teacher's questions, others might not answer, and especially when two children were close friends in the group they more easily responded to the situational questions asked by teachers.

The coordinator's and the researcher's log provided summary observations as follows: Results showed that pre-service teachers' teaching styles might need to strengthen their creativity in every way and employ it into other variety of activities, such as puppet shows or pictures designed, which helped them gain the children's attention as the teachers interacting with them. For example, some children liked to play with their classmates, so sometimes the children did not focus on the teacher. On the other hand, the teachers need to gain more understanding about learners' behavior conduct. That could help build up teacher-student relations in the process of actual teaching preparation for a future within the classroom.

Some pre-service teachers responded that storytelling as a strategy provides them to diminish speech anxiety in the real world and be less anxious about job interviews while using in English. Therefore, EFL children indicate engage in this action research via storytelling and extended group activities with the tutors and the peers.

\section{Conclusions}

In this study it was investigated how the intervention could benefit young EFL learners' short-term and/ or long-term memory retention through CL group activities. The results indicated that the questionnaire used by the valid and reliable measure of isolated expert designed. By discussing some of the ways in which the questionnaire has evolved since its use in this study, how it has been improved in related research and plans for its implementation in the future. Hence, this study's findings did not yield conclusive answers to the research questions. Yet, it has contributed to the growing studies in the area of CL storytelling action research for EFL children. Further studies addressing related teaching strategy need to consider measures for a more comprehensive understanding.

As regards storytelling use with pre-school EFL children, the current presentation is focused on the findings of a semester long cooperative action research undertaken with six junior EFL students. After the classroom telling of the four stories was completed, overall implications were generalized and listed as follows: 1 . 
Storytelling provides opportunities for children to engage in the lesson. 2. Extended group learning activities also increase children's attention. 3. Children are able to retell and/or create their own stories based on their own imagination. More specifically, storytelling seems to develop and motivate learners' interests; pre-school students seem eager to play the roles highlighted in the stories and be part of the stories. PTs noted that the cooperative processes seemed to help reinforce the PTs' storytelling techniques, while the action research processes provided the students with an opportunity to observe and learn from each other.

Lastly, if teachers can overcome difficulties in integrating more storytelling strategies into their classrooms applied within EFL classrooms, the quality of teaching and learning can be improved and students' enjoyment and success in EFL learning may increase.

\section{References}

Ahern, A. K., Bermejo, M. L. G., \& Fleta, T. (2008). Holistic learning through stories: Children's literature in the EFL classroom. In A. Poros, G. Lojová \& P. Bezúch (Eds.), ELT in primary education (pp. 98-103). Bratislava: Z-F Lingua.

Bas, G. (2008). Integrating multiple intelligences in ESL/EFL classroom [Electronic Version]. The Internet TESL Journal, 14, from http://iteslj.org/Techniques/Bas-IntegratingMultipleIntelligences.html

Chambers, D. W. (1970). Storytelling and creative drama. Dubuque: McGraw-Hill Higher Education.

Chien, Y. C., \& Huang, Y. K. (1999). Starting with predictable stories: EFL children's oral and literacy development. In Proceedings of the Ninth International Conference on English Teaching (pp. 264-273). Taipei: Crane.

Chomsky, C. (1972). Stages in language development and reading exposure. Harvard Educational Review, 42 , $1-33$.

Cohen, L., Manion, L., \& Morrison, K. (2007). Research methods in education. New York, NY: Routledge.

Cooper, J. L., Robinson, P., \& McKinney, M. (1990). Cooperative learning in the classroom. In D. F. Halpern \& Associates (Eds.), Changing college classrooms (pp. 74-92). San Francisco, CA: Jossey-Bass.

Cooper, P. (1989). Using storytelling to teach oral communication competencies $K-12$. Paper presented at the Annual Meeting of the Speech Communication Association.

Craig, R. R. (1996). Storytelling in the classroom: Some theoretical thoughts. Storytelling World, 9, 7-9.

Dodl, N. R. (1990). Instructional groupware: Design considerations. Paper presented at the 32nd Annual International conference of the association for the development of computer-based instructional systems.

Dujmović, M. (2006). Storytelling as a method of EFL teaching. Methodological Horizons, 1(1), 75-87.

Ersöz, A., Çakır, A., Cephe, P. T., Peker, B. G., Özkan, N., Büge, et al. (2006). English language curriculum for primary education (Grades 4, 5, 6, 7 and 8). Ankara: DevletKitapları Müdürlüğü.

Fitzgibbon, H., \& Wilhelm, K. H. (1998). Storytelling in ESL/EFL classrooms. TESL Reporter, 31(2), 21-31.

Gass, S., \& Mackey, A. (2007). Data elicitation for second and foreign language research. New Jersey: Routledge.

Green, M. C. (2004). Storytelling in teaching. Association for Psychological Science Observer, 17(4), 37-39.

Green, M. C., \& Brock, T. C. (2000). The role of transportation in the persuasiveness of public narratives. Journal of Personality and Social Psychology, 79, 401-421. http://dx.doi.org/10.1037/0022-3514.79.5.701

Hendrickson, J. M. (1992). Storytelling for foreign language learners. Retrieved from http://files.eric.ed.gov/fulltext/ED355824.pdf

Hoffer, E. (1955). The passionate state of mind and other aphorisms. New York: Harper Publishing.

Hung, S. (2009). Taiwanese parents' beliefs and children's English learning. Unpublished Masteral thesis. Ming Chuan University.

Johnson, D. W., \& Johnson, R. T. (1992). Positive interdependence: Key to effective cooperation. In R. Hertz-Lazarowitz \& N. Miller (Eds.), Interaction in cooperative groups: The theoretical anatomy of group learning (pp. 174-199). New York: Cambridge Univ. Press.

Lee, S.-Y. (2008). Storytelling and sustained silent reading in foreign language acquisition: Evidence from Taiwan. Retrieved from http://www.kzneducation.gov.za/Portals/0/ELITS\%20website\%20Homepage/IASL\%202008/profession al\%20papers/leepp.pdf

Ling, Y.-L. (2009). Storytelling for enriching EFL H.S. classes. Retrieved from http://english.tyhs.edu.tw/epaper/epaper35/teach_35.pdf 
Telling tales: Using storytelling to teach EFL kindergarten students in Taiwan

Mathews, H. (1992). The directive force of morality tales in a Mexican community. In R. D'Andrade \& C. Strauss (Eds.), Human motives and cultural models (pp. 127-162). New York: Cambridge University Press. http://dx.doi.org/10.1017/CBO9781139166515.007

McKernan, J. (1991). Curriculum action research. London: Kogan Page.

Olsen, R., \& Kagan, S. (1992). About cooperative learning. Englewood Cliffs, NJ: Prentice Hall.

Orr, J. (1997). The same but different: Classroom-based collaborative research and the work of classrooms. In H. Christiansen, L. Goulet, C. Krentz \& M. Maeers (Eds.), Recreating relationships: Collaboration and educational reform (pp. 247-262). New York: SUNY Press.

Pedersen, E. M. (1995). Storytelling and the art of teaching [Electronic Version]. Forum, 33, from http://dosfan.lib.uic.edu/usia/E-USIA/forum/vols/vol33/no1/P2.htm

Rich, Y. (1993). Education and instruction in the heterogeneous class. Springfield, IL: Charles C. Thomas.

Satish, A., Jain, R., \& Gupta, A. (2009). Tolkien: An event based storytelling system. Proceedings of the VLDB Endowment, 2(2), 1630-1633. http://dx.doi.org/10.14778/1687553.1687610

Schmuck, R. A., \& Schmuck, P. A. (1988). Group processes in the classroom (5th ed.). Dubuque, IA: William C. Brown.

Serrat, O. (2010). Storytelling. Washington, DC: Asian Development Bank.

Sharan, S. (1980). Cooperative learning in small groups: Recent methods and effects on achievement, attitudes, and ethnic relations. Review of Educational Research, 50(2), 241-271. http://dx.doi.org/10.3102/00346543050002241

Tsou, W., Wang, W., \& Tzeng, Y. (2006). Applying a multimedia storytelling website in foreign language learning. Computers \& Education, 47(1), 17-28. http://dx.doi.org/10.1016/j.compedu.2004.08.013

Wu, M.-L. (2008). 學英文從說故事開始 [xué yīng wén cóng shuō gù shì kāi shī]. Retrieved from http://www.parenting.com.tw/blog/blogTopic.action?id=73\&nid=368

Yolen, J. (1986). Favorite Folktales from around the World. New York: Random House. 
Hsu, T.-C. 